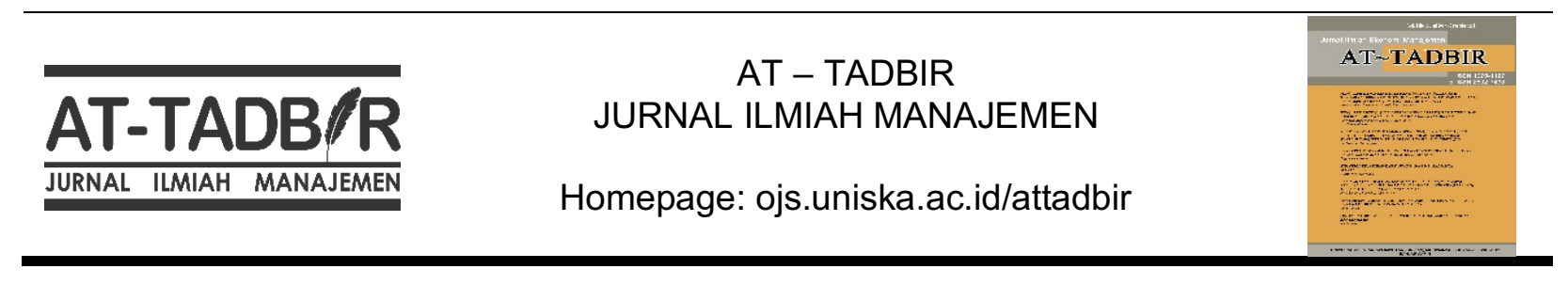

\title{
ASAS-ASAS KONTRAK (AKAD) DALAM HUKUM SYARI'AH
}

\author{
Akhmad Hulaify \\ Fakultas Studi Islam, Program Studi Ekonomi Syariah \\ Universitas Islam Kalimantan \\ Jl. Adhyaksa No. 2 Kayutangi Banjarmasin Kalimantan Selatan \\ E-mail: hulaify@gmail.com
}

\begin{abstract}
The position of the principles of contract ( $a q a d$ ) in Sharia law is a form protection of rights for economic transactions. This study examines the principles of contract (aqad) in sharia. This type of research is a library research. While the approach used in this study; normative approaches, sociological approaches, historical approaches and philosophical approaches. Data obtained from the literature were carried out reduction and classified then carried out to find the relationship between the data found with the core problem of this study. These results are analyzed using the method of analysis content with the aim of finding answers to the problems of this study. After analysis can be found the red thread that in Islamic Economics, contract is a determining factor of the immaturity of economic transactions. The emphasis is on the principle of circulation, principle of guarding, and principle of justice. The purpose of this study is to provide knowledge and understanding to the community that the principles of contract $(a q a d)$ in sharia are not only a form of agreement on a transaction but also as a bond between the two parties specifically regulated in the Islamic Economic system in order to avoid the mudharat (damage) and the safety of the world and hereafter (falah).
\end{abstract}

Keywords: Principle, Contract, Aqad, Law, Sharia

\begin{abstract}
Abstrak
Kedudukan asas-asas kontrak (akad) dalam hukum syari'ah merupakan bentuk perlindungan hak-hak bagi pelaku transaksi ekonomi. Penelitian ini mengkaji asas-asas kontrak (akad) dalam hukum syari'ah. Jenis penelitian ini termasuk kedalam penelitian library reseach (penelitian kepustakaan). Sedangkan pendekatan yang digunakan dalam penelitian ini menggunakan pendekatan normatif, pendekatan sosiologis, pendekatan historis dan pendekatan filosofis. Data yang diperoleh dari literatur-literatur dilakukan reduksi dan diklasifikasikan kemudian dilakukan untuk menemukan hubungan antara data yang ditemukan dengan inti masalah dari penelitian ini. Hasil tersebut dianalis dengan menggunakan metode analisis makna (analysis content) dengan tujuan menemukan jawaban atas permasalahan dari penelitian ini. Setelah dilakukan analisis dapat ditemukan benang merah bahwa dalam Ekonomi Islam, akad merupakan faktor penentu dari keabasahan sebuah transaksi ekonomi. Penekanannya pada prinsip sirkulasi, prinsip penjagaan, dan prinsip keadilan. Tujuan penelitian ini dimaksudkan untuk memberikan pengetahuan dan pemahaman kepada masyarakat bahwasanya asas-asas kontrak (akad) dalam hukum syari'ah bukan hanya sebagai bentuk kesepakatan terhadap sebuah transaksi akan tetapi juga sebagai sebuah pengikat antara kedua belah pihak yang diatur secara khusus dalam sistem Ekonomi Islam demi terhindar dari ke-mudharatan (kerusakan) serta keselamatan dunia dan akirat (falah).
\end{abstract}

Kata kunci: Asas, Kontrak, Akad, Hukum, Syariah 


\section{PENDAHULUAN}

Tiga dasawarsa kajian Ekonomi Islam mengalami kemajuan, baik dalam bentuk kajian akademis di Perguruan Tinggi maupun secara praktik operasional, baik di negaranegara muslim juga negara barat. Misalnya di Inggris ada beberapa universitas yang telah mengembangkan kajian ini seperti University of Durham, University of Portsmouth dan yang lainnya. Di Amerika sendiri dikaji di University of Harvard, bahkan Australia pun melakukan hal yang sama di University of Wolongong.

Indonesia dimana merupakan mayoritas muslim tentunya kajian ilmiah Ekonomi Syariah diselenggarakan universitas negeri maupun swasta. Sementara itu dalam bentuk prakteknya, ekonomi Islam telah berkembang dalam bentuk perbankan dan lembaga-lembaga keuangan Islam non bank. Perkembangan Ekonomi Islam di Indonesia mulai mendapatkan momentum yang berarti sejak didirikannya Bank Muamalat Indonesia pada tahun 1992. Pada saat itu sistem perbankan Islam memperoleh dasar hukum secara formal dengan berlakunya UndangUndang Nomor 7 Tahun 1992 tentang perbankan, sebagaimana yang telah direvisi dalam Undang-undang nomor 10 tahun 1998 dan dilengkapi oleh Undang-Undang Nomor 23 Tahun 1999 tentang Bank Indonesia. (Wiroyo, 2006).

Perekonomian berbasis Islam/Syariah diakui telah mengalami perkembangan pesat dan menggembirakan. Sejak Bank Muamalat Indonesia (BMI) berdiri dan mulai beroperasi pada 1 Mei tahun 1992, pertumbuhan perbankan syariah meningkat tajam. Dari satu bank umum syariah dan 78 BPRS pada tahun 1998 menjadi tiga bank umum syariah dan 17 bank umum yang membuka unit usaha syariah dengan 163 kantor cabang, 85 kantor cabang pembantu, dan 136 kantor kas, serta 90 BPRS pada akhir tahun 2005.
Kontribusi industri keuangan syariah memang masih kecil dibanding dominasi konvensional. Namun, tak bisa dipungkiri, tingkat pertumbuhannya amat pesat, dan terbukti tetap eksis kendati dihantam krisis moneter, beberapa tahun ke belakang. Dari sebuah riset yang dilakukan oleh Karim Business Consulting,diproyeksikan bahwa total asset bank syariah di Indonesia akan tumbuh sebesar $2850 \%$ selama 8 tahun, atau rata-rata tumbuh $356.25 \%$ tiap tahunnya. Yang juga cukup menggembirakan, ragam bisnis berbasis ekonomi syariah pun bertambah luas. Bukan hanya bidang perbankan, tapi juga memasuki wilayah asuransi, pasar modal, saham, pegadaian, dan lain-lain.

Melihat kian luas dan beragamnya pola bisnis berbasis perekonomian syariah, maka aspek perlindungan hukum dan penerapan asas kontrak dalam akad atau kontrak di Lembaga Keuangan Syari'ah menjadi penting diupayakan implementasinya. Dalam hal implementasi, para pelaku dan pengguna ekonomi syariah harus menjalankan kegiatannya berdasarkan syariah. Hubungan akad yang melandasi segenap transaksi inilah yang membedakannya dengan Lembaga Keuangan Konvensional, karena akad yang diterapkan di perbankan syari'ah dan lembaga keuangan syariah non bank lainnya, memiliki konsekuensi duniawi dan ukhrawi karena akad yang dilakukan berdasarkan hukum Islam. (Rahman, 1990). Dalam penerapan pola hubungan akad inilah sudah seharusnya tidak terdapat penyimpangan-penyimpangan atas kesepakatan yang telah dibuat oleh kedua belah pihak dari akad tersebut. Tetapi dalam koridor masyarakat yang sadar hukum, tidak dapat dihindari munculnya perilaku saling tuntut menuntut satu sama lain. Sehingga kuantitas dan kompleksitas perkara terutama perkara-perkara bisnis akan sangat tinggi dan beragam. Dalam hal ini kontrak disebut juga 
akad atau kontrak yaitu bertemunya ijab yang diberikan oleh salah satu pihak dengan kabul yang diberikan oleh pihak lainnya secara sah menurut hukum syar'i dan menimbulkan akibat pada subyek dan obyeknya. (Sholihin, 2010).

\section{TINJAUAN PUSTAKA}

Sebelum kita masuk dalam permbahasan mengenai akad, kiranya penting penulis untuk memberikan telaah pustaka. Dimana hal ini dimaksudkan untuk melihat bagaimana kerangka akad (kontrak) telah di kaji dari masa fiqih klasik samapai pada masa fiqih modern. Walaupun data yang tersaji belum sepunuhnya untuk mewakili dari sekian banyak penelitian yang ada, namun penulis berusaha untuk memberikan sajian yang singkat dan padat terhadap kajian mengenai permasalahan asas-asas akad (kontrak) dari sisi hukum syari'ah.

Ketika kita masuk dalam teori Ekonomi Islam khususnya di bidang Jual Beli (transaksi tukar menukar barang) maka hal yang terpentig adalah ketika terjadi sebuah kesepakatan. (Zuhaili, tt) Dalam kesepakatan kedua belah pihak diperlukan kontrak dalam hal ini adalah akad. (Ibrahim, tt). Kontrak (akad) menjadi penting karena dalam sebuah transaksi tidak akan sah apabila dia rusak bahkan hilang dalam arti tidak ada. (Firuzabadi, 1954) Tidak hanya di dunia Islam saja yang menekankan akan pentingnya akad di dunia barat pun juga sangat menekankan akan keberadaan akad.

Akan tetapi dalam teori Ekonomi Islam berbeda dalam memahami akad disini. Perbedaan tersebut terlihat dalam ketentuan akan unsur pendukung dari akad tersebut. Akad tidak akan menjadi sah (sempurna) apabila tidak adanya rukun dan syarat, hal ini tidak dimiliki dalam teori ekonomi Barat. Dalam teori ekonomi Barat hanya dikenal
Syarat saja akan tetapi tidak mengenal rukun (ketentuan utama). Islam memberikan dasar yang pasti menyangkut hal tersebut. Telaah menyangkut masalah kontrak banyak di kaji oleh ulama-ulama fiqih klasik maupun modern. Seperti halnya Ibn Taimiyah, Ibn Khaldun, Imam Malik, Imam Abu Hanifah dan lain.

Seperti halnya dalam kitab Bidayatul Mujtahid karangan Ibn Rusyd pembahasan akad telah di kemukan secara jelas dan lugas. Baik dari sisi dasar dala hal ini nas Al Qur'an dan Al Hadits dan tidak hanya itu analisa para fuqaha juga di bahas di sana. Kemudian juga dalam Fiqih Sunnah karangan Sayyid Sabiq, disana dibahas dengan mendalam menyangkut permasalahan akad.

Ilmuan fiqih modern pun seperti al Fathi Ad Diraini dari Mesir juga memberikan pembehasan mendalam menyangkut permasalah akad ini. Banyak lagi ilmuanilmuan fiqih yang lain membahas tentang akad ini.

Dari sekian banyak pembahasan yang ada, sedikit sekali menyinggung masalah implikasi sebuah asas dalam akad (kontrak) yang mengarah kepada perlindungan terhadap pengguna akad. (Khiraofa, 1997). Ini merupakan hal yang menarik dimana akad tidak hanya mengacu kepada permasalahan keabsahan dan keberlangsungan transaksi yang terjadi tetapi kepada masalah implikasi sebuah akad yang berdampak pada pelaku akan itu sendiri. Terkadang tidak jarang kalau dilihat dari sisi rukun dan syaratnya telah terpenuhi akan tetapi dari sisi manfaatnya terhadap pelaku dalam arti perlindungan terhadap sisi pelaku tidak terpenuhi. (Suyuti, 1981).

Ketidak pastian hukum dalam sebuah transaksi masih bisa dihindari namun yang terpenting disini adalah perlu adanya aturan khusus dalam syari'ah sehingga dapat 
memberikan kepastian hukum bagi pelaku yang melakukan transaksi. (Majid, 2004) Dan juga memberikan efek jangka panjang dalam perlindungan hukum syari'ah. Dimana aturan itu tidak hanya dibentuk untuk memberikan perlindungan tapi juga memberikan dampak pembatasan terjadinya unsur penipuan dalam sebuah transaksi.

Kajian-kajian yang membahas perlingdungan hukum dari sisi akad perlu kajian lebih mendalam. Ini dikarenakan problema akad tidak hanya tebatas pada sisi pelaku dan objeknya saja akan tetapi juga pengawasan terhadap implikasi dari tujuan transaksi yang terjadi. (Din, 1985) Pada dasarnya aturan hukum baik dari hukum positif maupun agama telah ada yang mangatur masalah perlindungan menyangkut pelaku transaksi namun hal tersebut terbatas pada sisi perlindungan saja tapi tidak dari sisi pengawasan. Sisi pengawasan ini penting dimana tujuannya dalah untuk membatasi ruang gerak terhadap pengingkaran terhadap akad (kontrak). Dari sisi inilah asas-asas hukum dalam akad (kontrak) penting untuk dikaji ulang dan dibahas lebih mendalam.

\section{METODE PENELITIAN}

\section{Jenis Penelitian}

Penelitian ini adalah penelitian pustaka (library Research) yang diperoleh dari sumber literature melalui reset kepustakaan. Penelitian ini diorientasikan untuk membahas bagaimana bagaimana konsep Kontrak (Akad) Dalam Hukum Kontrak Syari' ah yang tumbuh dan berkembang di dalam kehidupan masyarakat dan mengembangkannya dengan konsep Ekonomi Islam. Kemudian menggunakan metode deskriptif untuk mendiskripsikan atau menggambarkan situasi atau fenomena serta gejala-gejala yang ada, baik itu yang bersifat alamiyah atau rekayasa manusia. Penelitian daskriptif berusaha untuk mengkaji bentuk, aktivitas, krakteristik, perubahan, hubungan, kesamaan, dan perbedaannya dengan fenomena lainnya serta menguraikan bagaimana konsep Kontrak (Akad) Dalam Hukum Kontrak Syari'ah.

Metode pendekatan yang dipakai dalam penelitian ini ada tiga jenis pendekatan, yaitu pendekatan normatif, historis, sosiologis dan filosofis. Penelitian dengan menggunakan pendekatan normatif, menurut M. Amin Abdullah adalah upaya pendekatan memahamai agama dengan menggunakan empiris dari suatu agama yang dianggap paling benar. Dari pemahamaan tersebut maka bahwasanya penelitian ini bertitik tolak dari nash-nash al-Qur' an dan al-Sunnah serta teksteks Islam yang berkenaan dengan bagaimana konsep Kontrak (Akad) Dalam Hukum Kontrak Syari'ah ekonomi Islam, kemudian memberikan interprestasi hukum terhadap konsep Kontrak (Akad) Dalam Hukum Kontrak Syari'ah.

Kemudian penelitian ini menggunakan pendekatan historis dimaksudkan untuk melihat bagaimana awal mula konsep Kontrak (Akad) muncul dalam ranah hukum secara global. Kemudian dalam penelitian ini juga menggunakan pendekatan sosiologis. Hal ini dikarenakan dalam pendekatan sejarah tanpa melihat relitas kehidupan yang berkembang pada masa awal mula konsep Kontrak (Akad) muncul sampai kepada masa sekarang maka terlihat tidak lengkap. Dimana pendekatan sosiologis melihat perkembangan suatu teori dipengaruhi oleh perilaku sosial, hubungan sosial, serta konflik yang berkembang pada masa tersebut. (Abdurrahman, 1999).

Pendekatan yang terakhir adalah dengan menggunakan pendekatan filosofis. Pendekatan ini dimaksudkan untuk mengungkap pandangan Islam secara ideal terhadap konsep Kontrak (Akad) Dalam Hukum Kontrak Syari'ah serta mengungkap 
hikmah yang terkandung di dalam tema tersebut. Pada dasarnya pendekatan filosofis merupakan jalan yang sesuai untuk memahami lebih mendalam tentang hikmah yang terkandung dalam agama Islam yang tentunya bersumber dari al Qur'an dan al Sunnah.

\section{Teknik Pengumpulan dan jenis Data}

Sumber dalam penelitian ini adalah sumber yang dikumpulkan dari perpustakaan berupa buku-buku, dokumen dan lain sebagainya yang berkaitan dengan penelitian ini. Oleh karena itu sumber penelitian ini terbagi menjadi dua macam, yaitu :

Sumber primer, yaitu sumber atau literatur utama yang diperoleh dari buku-buku yang berkaitan lansung dengan objek penelitian, seperti dalam al Qur'an dan al Hadist, Haris Sulaiman al-Faruqi, al-Mu;jam al-qanuni Inklizi-'Arabi, Beirut: Maktabah Lubnan Nasyirun, tt. Subhiyy Mahmasaniy, 1948,al-Nazariyyat al- 'ammah li al-mujibat wa al-'uqud fi al-Shari'ah al-Islamiyyah, Mesir: Dar al-Kitab al-'arabiyy.

Sumber sekunder, yaitu sumber atau literatur yang diperoleh dari kajian-kajian sumber yang dapat digunakan sebagai penunjang dalam menganalisis masalahmasalah yang berkaitan seperti buku-buku, jurnal dan literatur lain yang berkaitan dengan konsep Kontrak (Akad) Dalam Hukum Kontrak Syari'ah.

\section{Metode Analisis Data}

Data-data yang terkumpul kemudian diklasifikasikan untuk mempermudah tahap selanjutnya yaitu analis teks. Di dalam kajian pustaka analisis ini disebut analisis makna (analysis content). Akan tetapi penulis dalam melakukan penelitian ini menggunakan analisis makna (Content analysis) yang bersifat inferensial yaitu suatu analisis yang menggunakan teknik yang sistematis dengan cara mengungkapkan lebih dalam pesan yang terkandung dalam konteks permasalahan dengan tidak mengurangi makan simbolik dan juga menggunakan konstrak analitis yang menggambarkan konteks masalah. (Zuchdi, 1993) Analisi disini merupakan gambaran teori yang berkenaan dengan konteks permasalahan sehingga permasalahan yang diteliti terinformasikan dengan jelas. Kemudian dalam penganalisisan tidak hanya terkait pada pesan itu sendiri, tetapi juga pada pertanyaan-pertanyaan yang lebih luas tentang peroses dan dampak dari fakta-fakta yang berhubungan dengan konsep Kontrak (Akad) Dalam Hukum Kontrak Syari'ah. Tahapan-tahapan yang akan dilakukan dalam melakukan penganalisisan ini diantaranya adalah, mengumpulkan data lalu melakukan kalisifikasi (kategorisasi) data dan reduksi (rangkuman), serta menyimpulkan sumber yang telah diperoleh agar dapat dipahami kemudian diinterpretasikan dengan baik kemudian mencari pola hubungan antara kesimpulan awal dengan konteks masalah serta permasalah yang menjadi pokok penelitian kemudian dilakukan analisis untuk mencapai sebuah kesimpulan (verifikasi) dari penelitian ini. Untuk kevalidan sumber yang akan diteliti peneliti mengacu kepada sumber asli yaitu berupa buku-buku maupun jurnal yang berkaitan langsung dengan pokok permasalahan dari konsep Kontrak (Akad) Dalam Hukum Kontrak Syari'ah. Yang menjadi unit analisis di sini adalah kata kunci yang terdiri dari akad, Syari'ah dalam ruang lingkup Kontrak (Akad) Dalam Hukum Kontrak Syari'ah

Proses Anaslis yang dilakukan sebagaimana tergambar pada bagan berkut ini:

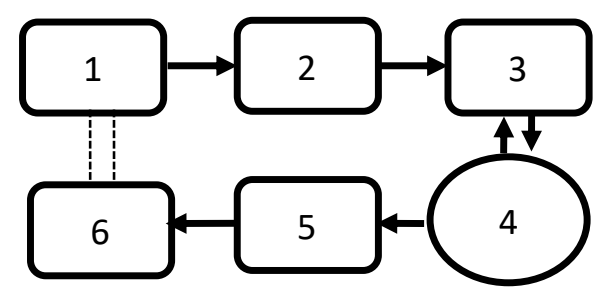


Keterangan :

1. Pengumpulan data

2. Reduksi Data

3. Kalifikasi Data

4. Verifikasi

5. Analisi Makna

6. Kesimpulan

\section{HASIL DAN PEMBAHASAN}

\section{Transaksi dan Kontrak (Akad) dalam} Syari'ah

Transaksi, dalam bahasa Arabnya sering dipersamakan dengan al-mu'amalah, sedangkan kontrak dipersamakan dengan alaqd. al-Mu'amalah sebagaimana disebutkan diatas, pengertiannya adalah suatu bidang fiqh yang memfokuskan pada hukum-hukum tentang perbuatan dan hubungan-hubungan sesama manusia mengenai harta kekayaan, hak, dan penyelesaian sengketa tentang halhal tersebut dalam rangka memenuhi kebutuhan sehari-hari mereka dengan berpandukan Syariah. Asas dalam transaksi Islam (muamalah) adalah akad (kontrak) yang menentukan cara dan kaedah perpindahan harta dalam Islam secara yang sah.

Dari penjelasan di atas, tergambar bahwa kontrak (al-aqd) adalah bagian penting dari muamalah. Dalam bahasa Arab, al-aqd berarti ikatan (al-ribt). (Firuzabadi, 1954) Menurut para ulama (seperti al-Jassas, al-Raghib alAsfahani, Abu Hayyan dan lain-lain), al-aqd diartikan sebagai ikatan secara maknawi, yakni ikatan antara perkataan yang diucapkan oleh dua pihak. (Qurahdaghi, 1985) Terdapat dua definisi berbeda di kalangan para ulama tentang maksud kontrak (al-aqd). Pendapat pertama menyatakan bahwa kontrak (al-aqd) adalah setiap tindakan yang bisa menimbulkan ikatan untuk memenuhinya baik antara dua pihak atau satu pihak saja. Ini adalah makna akad secara luas. Sedangkan pendapat kedua menyatakan bahwa kontrak $(a l-a q d)$ adalah setiap tindakan yang memerlukan kehendak dan persetujuan dua pihak dengan adanya ijab dan qabul. Ini adalah makna khusus akad yang dimaksud oleh mayoritas ulama fiqh. (Suyuti, 1981). Pengertian akad secara khusus yang diterima oleh banyak pakar fiqh adalah: (Din, 1985) "Pertalian ijab (yang disampaikan salah satu pihak yang mengadakan kontrak) dengan qabul (yang disampaikan pihak lain) dengan suatu cara yang menimbulkan pengaruh pada objek kontrak".

2. Unsur al-Taradi (Suka Sama Suka) dalam Kontrak

Al-Taradi (suka sama suka) dalam kontrak merupakan persyaratan yang paling mendasar dalam semua kontrak komersial dalam hukum Islam. (Din, 1985) Keridhaan ini bersifat subjectif yang tidak dapat diketahui kecuali dengan ekspresi nyata dari pihak yang bertransaksi, baik melalui katakata, tulisan, tindakan atau isyarat. Persetujuan secara rida (consent) untuk melakukan ijab dan qabul hanya dapat dilakukan oleh orang yang telah memiliki kecakapan (ahliyyah) yaitu baligh dan berakal.

Allah SWT memerintahkan kepada orang yang beriman agar hanya memperoleh keuntungan dari sesamanya hanya dengan jalan perniagaan (baik perniagaan barang atau jasa) yang berlaku secara rida sama rida. "Wahai orang-orang yang beriman, janganlah kamu saling memakan harta sesamamu dengan jalan yang batil, kecuali dengan jalan perniagaan yang berlaku secara rida sama rida di antara kamu". (Terjemahan Q.S. al-Nisa' (4): 29)

Dalam hadis juga disebutkan: "Jual beli itu hendaklah dilandasi suka sama suka". Ini menunjukkan bahwa Islam adalah agama yang menjamin perdamaian dan keharmonisan hidup manusia. Dalam kontrak, tidak selalu disyaratkan bahwa kedua-dua 
barang yang dikontrakkan itu mempunyai nilai yang sama, tetapi yang utama disyaratkan adalah adanya unsur suka sama suka (saling rida). Untuk itu, masing-masing pihak harus mempunyai informasi yang komplet sehingga tidak ada pihak yang merasa dicurangi atau ditipu karena adanya suatu yang tidak diketahui (assymmetric information). Informasi yang komplet itu meliputi empat aspek yaitu, kualitas, kuantitas, harga, dan waktu penyerahan. Jika empat hal itu tidak jelas bagi salah satu pihak, maka akan terjadi tadlis. Adanya tadlis dalam kontrak merupakan suatu pelanggaran terhadap prinsip suka sama suka. (Kirim, 2004).

Islam juga membolehkan melakukan kontrak yang hanya memberi keuntungan pada salah satu pihak saja, misalnya kontrak hibah, wasiat, sedekah, dan wakaf. Kontrak jenis ini hanya memberikan keuntungan kepada salah satu pihak saja, yaitu penerima, sedangkan pihak pemberi tidak mendapat apaapa (dalam arti materiil, secara spiritual tentu ia akan mendapat pahala dari Allah SWT sesuai dengan kadar keikhlasannya), asalkan ia memberi dengan penuh keridaan, maka kontrak semacam itu adalah sah dan halal. (Rahim, 1991)

3. Kebebasan dalam Melakukan Kontrak dan Meletakkan Syarat dalam Kontrak

Hadist yang berkaitan dengan kebebasan dalam melakukan kontrak dan meletakkan syarat dalam kontrak diriwayatkan oleh alBukhari, Abu Daud dan al-Bukhari, Abu Daud dan al-Turmudhi, bahwa Nabi Muhammad SAW bersabda yang artinya:

"Orang-orang Islam boleh melakukan kontrak dengan membuat apa-apa syarat melainkan syarat yang menghalalkan yang haram dan mengharamkan yang halal." (Turmudhi, 1967)."
Berdasarkan pada hadis tersebut, dapatlah dipahami bahwa hukum asal dari segala bentuk kontrak dan persyaratan adalah mubah. Ini sebagaimana pendapat mazhab Hambali dan Maliki. Mereka menyatakan bahwa transaksi dan persyaratan itu bebas, sehingga tidak ada yang diharamkan kecuali yang diindikasikan keharamannya oleh ajaran Islam, dengan dalil tegas atau qiyas. Di antara dalil-dalil mereka yang berpendapat demikian adalah sebagai berikut:

a. Asal dari kontrak adalah keridaan kedua belah pihak. Konsekuensinya adalah komitmen yang mereka sepakati bersama untuk mereka, sebagaimana firman Allah SWT dalam Q.S. al-Nisa'(4): 29. Allah melarang mengambil harta orang lain dengan cara batil (diharamkan), selanjutnya Allah mengecualikan harta yang diambil dari orang lain dengan saling ridha.

b. Al-Qur'an memerintahkan untuk memenuhi akad yang dibuat (Q.S. al-Ma'idah (5): 1). Ini menunjukkan bahwa janji atau kontrak itu wajib dilaksanakan tanpa kecuali dan kontrak itu tidak akan mengikat kecuali dilakukan dengan sah.

c. Kontrak dan persyaratan termasuk soal kebiasaan, dan asalnya adalah tidak diharamkan, karena asal dari kebiasaan adalah mubah, sebagaimana firman Allah SWT dalam Q.S. al-An'am (6):119. Hukum ini berlaku umum untuk benda dan perbuatan. Hukumnya dijadikan sebagai standar hukum asli hingga ada penjelasan tentang keharamannya.

Memang ada segolongan ulama' (mazhab Zahiri, diantaranya Ibnu Hazm) yang berpendapat sebaliknya, yaitu semua kontrak dan syarat-syarat adalah tidak sah kecuali yang dibolehkan oleh nas dan ijma'. (Hazm, tt). Akan tetapi, pendapat ini dianggap sempit dan kurang sesuai dengan semangat ajaran Islam itu sendiri. 
Secara garis besar, para ulama telah menggariskan tentang pembagian syarat dalam kontrak menjadi syarat sah dan syarat rusak atau batal. Masing-masing dibagi menjadi tiga yaitu: (Frank E Vogel dan Samuel L Hayes, 1998) Persyaratan yang sah:

1. Syarat yang menjadi konsekuensi perjanjian, seperti syarat harus ada serah terima barang dan penyerahan pembayaran.

2. Syarat demi kepentingan perjanjian, seperti syarat bentuk pembayaran, seperti pembayaran cash atau hutang (tunda).

3. Syarat yang jelas kegunaannya namun bukan merupakan konsekuensi perjanjian, dan juga bukan demi kepentingan perjanjian tersebut, namun juga tidak bertentangan dengan konsekuensi perjanjian itu. Seperti seorang penjual rumah yang meminta persyaratan untuk tetap tinggal di rumah itu selama satu bulan. (Muhyi, 2000)

Persyaratan yang rusak/batal:

a. Persyaratan yang menyimpang dari konsistensi untuk melaksanakan syarat dan rukun dasar suatu kontrak, dan persyaratan yang membuka pada masuknya elemen riba dan gharar, dan ilegal.

b. Persyaratan yang bertentangan dengan konsekuensi perjanjian. Seperti persyaratan bahwa barang yang dijual tidak boleh rugi bila dijual kembali, atau agar tidak dijual lagi.

c. Persyaratan yang membuat perjanjian menjadi tergantung. Seperti ucapan, "Aku jual ini kepadamu, tetapi bila si fulan sudah datang."

Kebolehan untuk meletakkan syarat dalam kontrak, tidak hanya dalam materi kontrak tetapi boleh juga syarat sanksi dalam kontrak dengan tujuan supaya kontrak berjalan mulus dan adil bagi semua pihak, kerana masing-masing memiliki rasa bertanggungjawab yang tinggi untuk menyelesaikan kewajibannya. Jika ia tidak menyelesaikan kewajibannya, maka ia terkena sanksi. Penentuan Sanksi/denda ini tidak boleh bersifat berlebih-lebihan, tetapi harus bersifat arif dan adil. Ketentuan dasar mejuruk kepada hukum-hukum Allah, termasuk sebab pengingkaran terhadap pemenuhan janji, sesuai firman Allah SWT dalam Q.S. al-Maidah (5): 1, dan juga sabda Rasulullah SAW yang artinya: "Tidak memudaratkan dan tidak dimudaratkan". (Nadhi, 1999).

Dalam konteks ini terdapat fatwa dari Idarah al-Buhuth wa al-Ifta' Majelis Ulama Besar Saudi Arabia menetapkan secara aklamasi bahwa syarat sanksi hukum yang diberlakukan dalam berbagai kontrak itu adalah syarat sah dan diakui kebenarannya, selama (yang melakukan kesalahan) tidak memiliki alasan yang dibenarkan syariat ketika ia menyalahi komitmen terhadap transaksi. Bila terhadap alasan yang dibenarkan syariat, maka sanksi itu tidak berlaku hingga alasan itu tidak ada lagi. (Abd al Haq Humaisy dan Al Husien Syawat, 2001).

4. Asas-Asas Kontrak (Akad) dalam Syari'ah

Asas berasal dari bahasa Arab asasun yang berarti dasar, basis dan fondasi. Secara terminologi asas adalah dasar atau sesuatu yang menjadi tumpuan berpikir atau berpendapat. Istilah lain yang memiliki arti sama dengan kata asas adalah prinsip yaitu dasar atau kebenaran yang menjadi pokok dasar berpikir, bertindak dan sebagainya. Mohammad Daud Ali mengartikan asas apabila dihubungkan dengan kata hukum adalah kebenaran yang dipergunakan sebagai tumpuan berpikir dan alasan pendapat terutama dalam penegakan dan pelaksanaan hukum. (Ali, 2000) Dari definisi tersebut apabila dikaitkan dengan perjanjian dalam 
hukum kontrak syariah adalah, kebenaran yang dipergunakan sebagai tumpuan berpikir dan alasan pendapat tentang perjanjian terutama dalam penegakan dan pelaksanaan hukum kontrak syari'ah. Dalam hukum kontrak syari'ah terdapat asas-asas perjanjian yang melandasi penegakan dan pelaksanaannya. Asas-asas perjanjian tersebut diklasifikasikan menjadi asas-asas perjanjian yang tidak berakibat hukum dan sifatnya umum dan asas-asas perjanjian yang berakibat hukum dan sifatnya khusus. Adapun asas-asas perjanjian yang tidak berakibat hukum dan sifatnya umum adalah :

a. Asas Ilahiah atau Asas Tauhid

Setiap tingkah laku dan perbuatan manusia tidak akan luput dari ketentuan Allah SWT. Seperti yang disebutkan dalam QS.alHadid (57): 4 yang artinya "Dia bersama kamu di mana saja kamu berada. Dan Allah maha melihat apa yang kamu kerjakan". Kegiatan mu'amalah termasuk perbuatan perjanjian, tidak pernah akan lepas dari nilainilai ketauhidan. Dengan demikian manusia memiliki tanggung jawab akan hal itu. Akibat dari penerapan asas ini, manusia tidak akan berbuat sekehendak hatinya karena segala perbuatannya akan mendapat balasan dari Allah SWT. (Syula, 2004).

b. Asas Kebolehan (Mabda al-Ibahah)

Terdapat kaidah fiqhiyah yang artinya," Pada asasnya segala sesuatu itu dibolehkan sampai terdapat dalil yang melarang”. (Masbukin, 2001 ) Kaidah fiqih tersebut bersumber pada dua hadis berikut ini: Hadis riwayat al Bazar dan at-Thabrani yang artinya:

"Apa-apa yang dihalalkan Allah adalah halal, dan apa-apa yang diharamkan Allah adalah haram, dan apa-apa yang didiamkan adalah dimaafkan. Maka terimalah dari Allah pemaaf-Nya. Sungguh Allah itu tidak melupakan sesuatupun”. (Masbukin, 2001 )
Hadis riwayat Daruquthni, dihasankan oleh an-Nawawi yang artinya:

Sesungguhnya Allah telah mewajibkan beberapa kewajiban, maka jangan kamu sia-siakan dia dan Allah telah memberikan beberapa batas, maka janganlah kamu langgar dia, dan Allah telah mengharamkan sesuatu maka janganlah kamu pertengkarkan dia,dan Allah telah mendiamkan beberapa hal, maka janganlah kamu perbincangkan dia.

Kedua hadis di atas menunjukkan bahwa segala sesuatunya adalah boleh atau mubah dilakukan. Kebolehan ini dibatasi sampai ada dasar hukum yang melarangnya.

c. Asas Keadilan (Al 'Adalah)

Dalam QS. Al-Hadid (57): 25 disebutkan bahwa Allah berfirman yang artinya:

"Sesungguhnya Kami telah mengutus rasulrasul Kami dengan membawa bukti-bukti yang nyata dan telah Kami turunkan bersama mereka al-Kitab dan Neraca (keadilan) supaya manusia dapat melaksanakan keadilan".

Selain itu disebutkan pula dalam QS.Al A'raf (7): 29 yang artinya:

"Tuhanku menyuruh supaya berlaku adil" Dalam asas ini para pihak yang melakukan kontrak dituntut untuk berlaku benar dalam mengungkapkan kehendak dan keadaan, memenuhi perjanjian yang telah mereka buat, dan memenuhi semua kewajibannya.

d. Asas Persamaan Atau Kesetaraan

Melakukan kontrak para pihak menentukan hak dan kewajiban masingmasing didasarkan pada asas persamaan dan kesetaraan. Tidak diperbolehkan terdapat kezaliman yang dilakukan dalam kontrak tersebut. Sehingga tidak diperbolehkan membeda-bedakan manusia berdasar perbedaan warna kulit, agama, adat dan ras. 
Dalam QS.al-Hujurat (49): 13 disebutkan yang artinya " Hai manusia sesungguhnya kami menciptakan kamu dari seorang lakilaki dan seorang perempuan dan menjadikan kamu berbangsa-bangsa dan bersuku-suku supaya kamu saling mengenal"

e. Asas Kejujuran dan Kebenaran (Ash Shidiq)

Jika kejujuran ini tidak diterapkan dalam kontrak, maka akan merusak legalitas kontrak dan menimbulkan perselisihan diantara para pihak. QS.al-Ahzab (33) : 70 disebutkan yang artinya, " Hai orang - orang yang beriman, bertaqwalah kamu kepada Allah dan katakanlah perkataan yang benar". Suatu perjanjian dapat dikatakan benar apabila memiliki manfaat bagi para pihak yang melakukan perjanjian dan bagi masyarakat dan lingkungannya. Sedangkan perjanjian yang mendatangkan madharat dilarang.

f. Asas Tertulis ( Al Kitabah)

Suatu perjanjian hendaknya dilakukan secara tertulis agar dapat dijadikan sebagai alat bukti apabila di kemudian hari terjadi persengketaan. Dalam QS.al-Baqarah (2); 282- 283 dapat dipahami bahwa Allah SWT menganjurkan kepada manusia agar suatu perjanjian dilakukan secara tertulis, dihadiri para saksi dan diberikan tanggung jawab individu yang melakukan perjanjian dan yang menjadi saksi tersebut. Selain itu dianjurkan pula jika suatu perjanjian dilaksanakan tidak secara tunai maka dapat dipegang suatu benda sebagai jaminannya.

g. Asas Iktikad baik (Asas Kepercayaan)

Asas ini dapat disimpulkan dari pasal 1338 ayat (3) KUH Perdata yang berbunyi, “ Perjanjian harus dilaksanakan dengan iktikad baik". Asas ini mengandung pengertian bahwa para pihak dalam suatu perjanjian harus melaksanakan substansi kontrak atau prestasi berdasarkan kepercayaan atau keyakinan yang teguh serta kemauan baik dari para pihak agar tercapai tujuan perjanjian.

h. Asas Kemanfaatan dan Kemaslahatan

Asas ini mengandung pengertian bahwa semua bentuk perjanjian yang dilakukan harus mendatangkan kemanfaatan dan kemaslahatan baik bagi para pihak yang mengikatkan diri dalam perjanjian maupun bagi masyarakat sekitar meskipun tidak terdapat ketentuannya dalam al Qur'an dan Al Hadis. (Muharrom, 2003) Asas kemanfaatan dan kemaslahatan ini sangat relevan dengan tujuan hukum Islam secara universal. Sebagaimana para filosof Islam di masa lampau seperti al-Ghazali ( w.505/1111) dan asy-Syatibi (w 790/1388) merumuskan tujuan hukum Islam berdasarkan ayat-ayat al-Qur'an dan al-Hadis sebagai mewujudkan kemaslahatan. Dengan maslahat dimaksudkan memenuhi dan melindungi lima kepentingan pokok manusia yaitu melindungi religiusitas, jiwa-raga, akal-pikiran, martabat diri dan keluarga, serta harta kekayaan. (Ghazali, 1971)

Sedangkan asas-asas perjanjian yang berakibat hukum dan bersifat khusus adalah:

a. Asas Konsensualisme atau Asas Kerelaan (mabda' ar-rada'iyyah)

Dalam QS. An-Nisa (4): 29 yang artinya: " Hai orang-orang yang beriman, janganlah kamu saling memakan harta sesamamu dengan jalan yang batil, kecuali dengan jalan perniagaan yang berlaku dengan suka sama suka di antara kamu”, dari ayat di atas dapat dipahami bahwa segala transaksi yang dilakukan harus atas dasar suka sama suka atau kerelaan antara masing-masing pihak tidak diperbolehkan ada tekanan, paksaan, penipuan, dan mis-statement. Jika hal ini tidak dipenuhi maka transaksi tersebut dilakukan dengan cara yang batil. (DJamil, 2001) Asas ini terdapat juga dalam hadis riwayat Ibn Hibban dan al-Baihaqi yang artinya: “ 
Sesungguhnya jual beli berdasarkan perizinan (rida)".

Selain itu asas ini dapat pula di lihat dalam pasal 1320 ayat (1) KUH Perdata. Dalam pasal tersebut ditentukan bahwa salah satu syarat sahnya perjanjian yaitu adanya kesepakatan kedua belah pihak. Asas konsensualisme merupakan asas yang menyatakan bahwa perjanjian pada umumnya tidak diadakan secara formal, tetapi cukup dengan adanya kesepakatan kedua belah pihak, yang merupakan persesuaian antara kehendak dan pernyataan yang dibuat oleh kedua belah pihak.

b. Asas Kebebasan Berkontrak (mabda' hurriyah at-ta'aqud)

Islam memberikan kebebasan kepada para pihak untuk melakukan suatu perikatan. Bentuk dan isi perikatan tersebut ditentukan ditentukan oleh para pihak. Apabila telah disepakati bentuk dan isinya, maka perikatan tersebut mengikat para pihak yang menyepakatinya dan harus dilaksanakan segala hak dan kewajibannya. Namun kebebasan ini tidak absolute. Sepanjang tidak bertentangan dengan syari'ah Islam, maka perikatan tersebut boleh dilaksanakan. Menurut Faturrahman Djamil bahwa, " Syari'ah Islam memberikan kebebasan kepada setiap orang yang melakukan akad sesuai dengan yang diinginkan, tetapi yang menentukan syarat sahnya adalah ajaran agama." Dalam QS.al-Maidah (5): 1 disebutkan, yang artinya " Hai orang-orang yang beriman, penuhilah perjanjian-perjanjian

c. Asas Perjanjian Itu Mengikat

Asas ini berasal dari hadis Nabi Muhammad saw yang artinya:

"Orang-orang muslim itu terikat kepada perjanjian-perjanjian (Klausul-klausul) mereka, kecuali perjanjian (klausul) yang mengharamkan yang halal atau menghalalkan yang haram".

Dari hadis tersebut dapat dipahami bahwa setiap orang yang melakukan perjanjian terikat kepada isi perjanjian yang telah disepakati bersama pihak lain dalam perjanjian. Sehingga seluruh isi perjanjian adalah sebagai peraturan yang wajib dilakukan oleh para pihak yang mengikatkan diri dalam perjanjian.

d. Asas Keseimbangan Prestasi

Asas ini adalah asas yang menghendaki kedua belah pihak memenuhi dan melaksanakan perjanjian. Dalam hal ini dapat diberikan ilustrasi, kreditur mempunyai kekuatan untuk menuntut prestasi dan jika diperlukan dapat menuntut pelunasan prestasi melalui harta debitur, namun debitur memikul pula kewajiban untuk melaksanakan perjanjian itu dengan iktikad baik.

e. Asas Kepastian Hukum (Asas Pacta Sunt Servanda)

Asas kepastian hukum ini disebut secara umum dalam kalimat terakhir QS. Bani Israil (17): 15 yang artinya, “....dan tidaklah Kami menjatuhkan hukuman kecuali setelah Kami mengutus seorang Rasul untuk menjelaskan (aturan dan ancaman) hukuman itu...." Selanjutnya di dalam QS. Al-Maidah (5) : 95 dapat dipahami Allah mengampuni apa yang terjadi di masa lalu. Dari kedua ayat tersebut di atas dapat disimpulkan bahwa asas kepastian hukum adalah tidak ada suatu perbuatanpun dapat dihukum kecuali atas kekuatan ketentuan peraturan perundangundangan yang ada dan berlaku untuk perbuatan tersebut.

Asas kepastian hukum ini terkait dengan akibat perjanjian. Dalam hal ini hakim atau pihak ketiga harus menghormati substansi kontrak yang dibuat oleh para pihak, sebagaimana layaknya sebuah undangundang, mereka tidak boleh melakukan 
intervensi terhadap substansi kontrak yang dibuat oleh para pihak. Asas Pacta Sunt Servanda dapat disimpulkan dalam pasal 1338 ayat (1) KUH Perdata, yang berbunyi, "Perjanjian yang dibuat secara sah berlaku sebagai undang-undang”.

a. Asas Kepribadian (Personalitas)

Asas kepribadian merupakan asas yang menentukan bahwa seseorang yang akan melakukan dan atau membuat kontrak hanya untuk kepentingan perseorangan. Hal ini dapat dipahami dari bunyi pasal 1315 dan pasal 1340 KUH Perdata. Pasal 1315 KUH Perdata berbunyi “ Pada umumnya seseorang tidak dapat mengadakan perikatan atau perjanjian selain untuk dirinya sendiri”. Sedangkan pasal 1340 KUH Perdata berbunyi "Perjanjian hanya berlaku antara para pihak yang membuatnya “. Namun ketentuan ini terdapat pengecualian sebagaimana yang diintrodusir dalam pasal 1317 KUH Perdata yang berbunyi " Dapat pula perjanjian diadakan untuk kepentingan pihak ketiga, bila suatu perjanjian yang dibuat untuk diri sendiri atau suatu pemberian kepada orang lain mengandung suatu syarat semacam itu ". Pasal ini mengkonstruksikan bahwa seseorang dapat mengadakan perjanjian untuk kepentingan pihak ketiga dengan suatu syarat yang ditentukan. Sedangkan di dalam pasal 1318 KUH Perdata tidak hanya mengatur perjanjian untuk diri sendiri tetapi juga untuk kepentingan ahli warisnya dan untuk orangorang yang memperoleh hak daripadanya.

\section{f. Asas Kebebasan Berkontrak}

Dalam asas-asas perjanjian Islam dianut apa yang disebut dalam ilmu hukum sebagai "asas kebebasan berkontrak" (mabda' hurriyah al-ta'aqud). Asas ini penting untuk dielaborasi lebih lanjut mengingat suatu pertanyaan, apakah konsep dan bentuk transaksi atau akad yang terdapat dalam kitabkitab fiqih tanpa ada keleluasaan kaum muslimin untuk mengembangkan bentukbentuk akad baru sesuai dengan perkembangan dan kebutuhan masyarakat.

Dalam asas kebebasan berkontrak, dimaksudkan kebebasan seseorang untuk membuat perjanjian macam apapun dan berisi apa saja sesuai dengan kepentingannya dalam batas-batas kesusilaan dan ketertiban umum, sekalipun perjanjian tersebut bertentangan dengan aturan-aturan atau pasal-pasal hukum perjanjian.

Menurut al-Zarqa kebebasan berkontrak itu meliputi empat segi kebebasan yaitu:

1. Kebebasan untuk mengadakan atau tidak mengadakan perjanjian

2. Tidak terikat kepada formalitasformalitas, tetapi cukup semata-mata berdasarkan kata sepakata (perizinan).

3. Tidak terikat kepada perjanjianperjanjian bernama

4. Kebebasan untuk menentukan akibat perjanjian. (Zarqa, 1968)

Sabda Nabi dalam hadis 'Amr Bin Auf, yang dikonfirmasikan oleh hadis $\mathrm{Abu}$ Hurairah disebutkan bahwa "As-Sulhu ja-iz baina al-Muslimin" menyatakan bahwa kaum muslimin dibenarkan membuat perjanjian perdamaian dalam pelaksanaan hak-hak mereka, namun kebolehan tersebut berlaku dalam batas-batas sepanjang tidak melanggar ketentuan halal dan haram seperti dapat dimengerti dari lanjutan sabdanya, "illa salhan harrama halalan aw ahalla harraman"

Kebebasan berkontrak lebih Nampak jelas dalam sabda beliau yang merupakan lanjutan yaitu "wal muslimun 'ala syurutihim illa syartan halalan aw ahalla harraman" Di sini kaum muslimin dibenarkan memperjanjikan syarat-syarat dan perjanjian itu mengikat untuk dipenuhi dalam batasbatas ketentuan halal dan haram. Kata syurut 
adalah bentuk jama' yang diidafahkan kepada kata ganti "mereka". Kasus ini menunjukkan bahwa dia termasuk lafal umum, sehingga hal itu berarti bahwa kaum muslimin dapat mengisikan syarat apa saja ke dalam perjanjian mereka dalam batas-batas ketentuan halal dan haram, artinya dalam batas-batas ketertiban umum syara'.

Para ulama dalam masalah kebebasan berkontrak khususnya dalam memperjanjikan syarat-syarat secara garis besar terbagi ke dalam dua kutub yang berlawanan. Yang paling tidak mengakui asas kebebasan berkontrak adalah ulama-ulama Zahiri, khususnya Ibn Hazm, dan yang paling luas mengakui asas tersebut serta paling banyak mentashih syarat-syarat adalah ulama-ulama Hanabilah, khususnya Ibn Taimiyah. (Yusdani, 2002)

Bagi Ibn Hazm pada asasnya akad dan syarat itu haram dipenuhi kecuali yang diperintahkan oleh nash agar dipenuhi. Ibn Hazm berpendapat bahwa setiap syarat sebutan syarat dalam pengertian yang diberikan oleh Ibn hazm meliputi akad dan janji sepihak yang tidak di tegaskan keabsahannya oleh nash merupakan syarat yang tidak terdapat pada kitab Allah dan" jika para pihak menyebutkan syarat-syarat itu pada waktu membuat akad jual beli maka jual beli itu batal dan syarat-syarat tersebut juga batal." (Hazm, tt) Syarat yang sah telah ditegaskan keabsahannya oleh nash dan karena itu merupakan syarat yangb terdapat dalam kitab Allah. Menurut Ibn Hazm hanya terdapat tujuh macam syarat sebagai berikut:

1. Mensyaratkan gadai dalam jual beli tidak tunai (sebagai jaminan pembayaran hutang)

2. Mensyaratkan penundaan pembayaran harga sampai pada waktu yang ditentukan

3. Syarat pembayaran harga pada waktu longgar
4. Mensyaratkan sifat tertentu pada barang

5. Mensyaratkan tidak ada pengicuhan

6. Mensyaratkan harta benda milik budak yang dijual oleh tuannya adalah untuk pembeli baik sebagiannya maupun seluruhnya

7. Mensyaratkan bahwa buah pohon yang te;lah dikawinkan yang dijual oleh pemiliknya adalah untuk pembeli baik sebagian maupun seluruhnya. Syaratsyarat di luar criteria yang tujuh tersebut menurut tokoh mazhab Zahiri adalah batal.

Selain dari pendapat Ibn Hazm ini terdapat pendapat Ibn Taimiyah yang mewakili mazhab Hanbali. Ibn Taimiyah telah membawa perkembangan mazhab Hanbali dalam hal kebebasan berkontrak sejajar atau hampir sejajar dengan hukum barat. Bagi Ibn Taimiyah tidak hanya sah syarat-syarat dalam perjanjian-perjanjian kebendaan bahkan juga sah syarat-syarat dalam perjanjian pernikahan. Misalnya calon suami isteri dapat mensyaratkan sesuatu sehubungan dengan harta bendanya dalam perkawinan.

Menurut Ibn Taimiyah syarat yang terdapat dalam kitab Allah bukan hanya syarat yang disebutkan namanya saja tetapi yang dimaksud adalah syarat yang tidak bertentangan dengan kitab Allah sekalipun tidak disinggung baik oleh nash al Qur'an maupun hadits. (Taimyyah, $t \mathrm{t}$ ). Asas kebebasan berkontrak sebenarnya jelas diajarkan oleh nash-nash Al Qur'an, Al Hadis dan terdapat pula dalam kaidah-kaidah fiqhiyah. Dengan demikian hadis 'Amr Bin Auf walaupun lemah dari segi sanad, maknanya sesuai dan didukung oleh Al Qur'an dan Al Hadis. Dalam QS. al-Maidah ayat (1) Allah berfirman yang artinya "Wahai orang-orang beriman, penuhilah perjanjianperjanjian (Akad)" kata akad dalam ayat ini berbentuk jamak yang yang diberi alif- lam sehingga menjadikannya sebagai lafal umum. 
Jadi ayat ini mencakup segala macam akad baik yang timbal balik maupun yang sepihak dan semua syarat yang seseorang mengikatkan diri untuk melaksanakannya di masa depan. Sedangkan surat al-Nisa' ayat (29) membatasi kebebasan tersebut dalam batas-batas tidak memakan harta orang lain dengan jalan batil dan hal inilah merupakan ketertiban umum syara'

Dalam hadis-hadis terdapat banyak contoh Rasulullah saw menerapkan asas kebebasan berkontrak . Hadis Jabir yang di riwayatkan oleh Bukhari dalam sahihnya menjelaskan bahwa Jabir telah menjual untanya kepada Rasulullah saw dengan memasukkan ke dalam perjanjian jual beli tersebut syarat bahwa ia dapat memanfaatkan unta yang sudah dijualnya kepada Rasul untuk pulang ke Madinah. Memang di sini ulama berbeda pendapat dimana ada yang menyatakan bahwa pemanfaatan oleh Jabir itu adalah tabarru' dari Rasulullah saw sementara ulama yang lain menyatakannya sebagai syarat yang dimasukkan dalam akad jual beli. (Sanhuri, 1981).

\section{KESIMPULAN DAN SARAN}

\section{Kesimpulan}

Dari paparan-paparan terdahulu, sebagai penutup perlu dikemukakan kesimpulankesimpulan sebagai berikut:

Dalam hukum kontrak syariah, paling tidak terdapat 14 macam asas kontrak yang dapat digunakan sebagai landasan berpikir dan bertransaksi dalam penegakan hukum kontrak syariah tersebut. Asas-asas kontrak itu adalah, Asas ilahiah, asas konsensualitas, asas kebebasan berkontrak, asas kebolehan, asas kontrak itu mengikat, asas keseimbangan prestasi, asas keadilan, asas persamaan, asas kejujuran, asas tertulis, asas kepastian hukum, asas iktikad baik,asas kepribadian, dan asas kemanfaatan atau kemaslahatan. Salah satu asas dalam asas kontrak ada yang dinamakan asas kebebasan berkontrak.

Dengan asas kebebasan berkontrak tersebut kaum muslimin mempunyai kebebasan untuk membentuk akad-akad baru selama tidak bertentangan dengan prinsipprinsip dan tujuan hukum Islam. Dengan demikian fiqih mu'amalah dapat dikembangkan secara dinamis dalam rangka menjawab persoalan-persoalan baru ekonomi kontemporer.

\section{Saran}

Dalam merespon perkembangan bentuk-bentuk baru dalam bertransaksi sudah seharusnya ahli fiqih mu'amalah disamping menguasai prinsip-prinsip dan asas-asas umum hukum Islam itu sendiri, juga mengetahui praktek-praktek mu'amalah kontemporer yang banyak dikuasai oleh ahli ekonomi konvensional pada umumnya. Hal ini penting dilakukan karena, bagaimana mungkin penetapan hukum atas bentukbentuk mu'amalah kontemporer dalam hal ini kontrak,menjadi akurat jika masalah mu'amalah kontemporer itu sendiri tidak dipahami.

Model kajian fiqih mu'amalah dewasa ini disamping model kajian konseptual teoritik, juga sudah saatnya dikombinasikan dengan model kajian empirik atas persoalanpersoalan ekonomi kontemporer, sehingga penguasaan kedua metodologi kajian fiqih mu'amalah lebih .

Keterbatasan pada model penelitian fiqih adalah kepada ketersediaan literaturliteratur klasik. Padahal dasar kajian dalam model penelitian seperti ini adala mengacu kepada kajian-kajian klasik. Kondisi tersebut juga menjadi sebuah kendala dalam mengkaji model penelitian seperti ini. Sehingga perlu konsistensi tentang pengembangan kajiankajian fiqih. 


\section{DAFTAR PUSTAKA}

Abd al-Razzaq al- Sanhuri (1981), Masadir al-Haq fi al-Fiqh al-Islami, juz 1. Beirut: al-Majma' al-'Arabi al-Islami.

Abd al-Haq Humaisy dan al-Husein Syawat (2001), Fiqh al-'Uqud al-Maliyyah. 'Amman (Jordan): Dar al-Bayariq.

Abdul Rahim (1991), The Principle of Muhammadan Jurisprudence. Lahore: The Pakistan Educational Press.

al-Fiyruzabadi (1983), al-Qamus al-Muhit. Beirut: Dar al-Fikr, h. 3079; Ibn Manzur (1954)

Ali Ahmad al-Nadwi (1999), Mausu'ah alQawa'id wa al-Dawabit al-Fiqhiyyah, Beirut: Dar 'Alam al-Ma'rifah.

Ali Muhyi al-Din 'Ali al-Qurahdaghi (1985), Mabda' al-Rida fi al- 'Uqud, juz 1, Beirut: Dar al-Basya'ir al-Islamiyyah.

Ali, Mohammad Daud, 2000, Asas-asas Hukum Islam,cet. Ke-5, (Jakarta: CV.Rajawali)

al-Suyuti (1998), op.cit, h. 318; Syams al-Din al-Syaikh Muhammad al- Dasuqi (t.t.), Hasyiyah al-Dasuqi 'ala al-Syarh alKabir, juz 3. Beirut: Dar al-Fikr,

Al-Zarqa,1968,al-Fiqh al-Islami fi Sauhihi alJadid, cet.ke-9,Damaskus: Matabi' Alifba 'al-Adib

Anderson,J.N.D, 1975, Islamic Law in The Modern World, (London: The University of London Press)

Bukhari, Abu Abdillah Muhammad ibn Ismail al-, tt, Sahih al-Bukhari, (Surabaya: Ahmad Nabhan)

Darmiyati Zuchdi, Panduan Penelitian analisis Konten, 1993 (Yogyakarta: Lembaga Penelitian IKIP Yogyakarta,).

Dudung Abdurrahman, 1999, Metode Penelitian Sejarah, (Jakarta: PT Logos Wacana Ilmu)

Fath, Ahmad Abu al-, 1913, Kitab alMu'amalat fi asy-Syari'ah al-Islamiyah wa al- Qawanin al-Misriyyah, (Mesir: Matba'ah al-Burfur)

Frank E. Vogel dan Samuel L. Hayes (1998), Islamic Law and Finance, London: Kluwer Law International, hh. 100-102; Mohd. Ma'sum Billah (2003)
Ghazali, Al-, 1971, al-Mustasfa min Ilm alUsul, (Kairo: Syirkah at-Tiba'ah al-

Hakim, Tt, Al-Mustadrak, (Riyad: Maktabah wa Mattabi’ al-Nashyr al-Hadis )

Hazm, Ibn, Tt, Al-Muhalla, VIII, (Beirut: alMaktab al-Tijari)

-------, t.t., al-Muhalla, Beirut: Dar al-Afaq alJadidah, jil. 8.

Taymiyyah, t.t, Nazariyyah al-'Aqd. Beirut: Dar al-Ma'rifah.

M.Tamyiz Muharrom, 2003, "Kontrak Kerja: Antara Kesepakatan dan Tuntutan Pengembangan SDM", dalam Al Mawarid Jurnal Hukum Islam, Edisi X tahun 2003, Yogyakarta: Program Studi Syari' ah FIAI UII

Mohammad Daud Ali,2000,Hukum Islam: Pengantar Ilmu Hukum dan Tata Hukum Islam di Indonesia, cetakan ke-8, Jakarta: Raja Grafindo Persada.

Mukharrom, Tamyiz, M, 2003, “ Kontrak Kerja Antara Kesepakatan dan Tuntutan Pengembangan SDM" dalam Jurnal Hukum Islam Al Mawarid Edisi X tahun 2003, (Yogyakarta: Program Studi Syari'ah FIAI UII)

Syatibi, Asy, 1341, al-Muwafaqat fi usul alAhkam II, (Ttp: Dar al-Fikr)

-----,tt, Majmu' al-Fatawa, IX, Riyad: Matabi' al-Riyad.

Turmudhi (1967), Sunan al-Turmudhi (alJami' al-Sahih), juz 3, Kairo:Maktabah al-Babi al-Halabi, h. 635. Hadis Hasan Sahih.

Yusdani, 2002, "Transaksi (Akad) dalam Perspektif Hukum Islam", dalam Jurnal Studi Agama MILLAH Vol.II, Nomor 2, Januari 2002, (Yogyakarta: Magister Studi Islam UII)

Zarqa,1968,al-Fiqh al-Islami fi Sauhihi alJadid, cet.ke-9,(Damaskus: Matabi' Alifba 'al-Adib) 